\title{
Changing Global Production Network and Its Implication on Belt and Road Initiative
} Author(s): Prem Chhetri, Victor Gekara, Shaorong Li, Jun Yeop Lee

Source: Journal of International Logistics and Trade 2020; 18(1):13-14

Published by: Jungseok Research Institute of International Logistics and Trade, Inha University

DOI: https://doi.org/10.24006/jilt.2020.18.1.013

The Journal of International Logistics and Trade is an official journal published by Jungseok Research Institute of International Logistics and Trade, Inha University, Korea. JILT welcomes manuscripts that advance the practice and science of logistics, trade, and other related fields.

Frequency: Quarterly (March, June, September, December)

Stable URL: https://www.ejilt.org

The Jungseok Research Institute of International Logistics and Trade is a specialized academic research institute representing Inha University and the Inha Foundation in Korea. The institute aims to become a representative institute in Northeast Asia in the research of logistics and trade.

Stable URL: https://jrieng.inha.ac.kr

(C) Copyright. Jungseok Research Institute of International Logistics and Trade.

This is an Open-Access article distributed under the terms of the Creative Commons Attribution NonCommercial License (http://creativecommons.org/licenses/by-nc/4.0/) which permits unrestricted noncommercial use, distribution, and reproduction in any medium, provided the original work is properly cited 


\title{
Journal of International Logistics and Trade
}

J. Int. Logist. Trade, 2020, Vol. 18, No. 1, 13-14

pISSN : 1738-2122 eISSN : 2508-7592

https://doi.org/10.24006/jilt.2020.18.1.013

https://www.ejilt.org

\section{EDITORIAL}

\section{Changing global production network and its implication on Belt and Road Initiative}

\author{
Prem Chhetri ${ }^{1{ }^{1}}{ }^{,}$, Victor Gekara ${ }^{1}$, Shaorong $\mathrm{Li}^{2}$, Jun Yeop Lee ${ }^{3}$ \\ ${ }^{1}$ Business IT and Logistics, RMIT University, Melbourne, Australia \\ ${ }^{2} S c h o o l$ of Economics, Peking University, Beijing, China \\ ${ }^{3}$ Department of International Trade and Regional Studies, Inha University, Incheon, Korea
}

\author{
Received March 01, 2020 \\ Revised March 25, 2020 \\ Accepted March 27, 2020 \\ *Corresponding author: Prem Chhetri \\ Business IT and Logistics, RMIT \\ University, Melbourne, Australia \\ Tel: +61-3-9925-1392 \\ Fax: +61-3-99255624 \\ E-mail: prem.chhetri@rmit.edu.au
}

\begin{abstract}
This editorial establishes the broader context for debating the great global convergence of world economic systems and the role of Belt and Road Initiative in shaping the reconfiguration of key global transport nodes and trade corridors. The interwoven relationships between various aspects of technological transformation, supply chain integration and demographic restructuring in shaping the global value chain and integrated production networks are theoretically and empirically probed in this special issue. The importance of technological innovation, and structural reforms are highlighted to help businesses to sustainably manage the growing supply chain complexity and the likely disruptions during the fourth industrial revolution.
\end{abstract}

Keywords Belt and Road Initiative, Technological transformations, Supply chain integration, Population ageing

The U.S. and China, the world's two largest economies, signed a phase-one trade deal in January 2020, which was perceived as a temporary truce to the current trade war that has threatened to derail the global economy. The trade war appeared to be triggered directly by the dispute over China's continuing trade surplus with the U.S. There are however other aspects to the antagonism. The first is the geopolitical competition aspect. China's move to consolidate its dominance in the Asean region and spread its influence in the developing world, notably Africa and Latin America, has been viewed as direct challenge to the American global hegemony and likely to significantly alter the prevailing order of the global economy and geopolitics (Allison, 2017).

Second is the data war aspect. In the $21^{\text {st }}$ Century and with the emerging fourth industrial revolution, information technology and electronic data have become important weapons with implications for global and national security and control of global supply chains. The two superpowers have thus found themselves locked in the battle for the control of global information and data flows. Because the emerging data economy has the characteristics of "winner takes all”, China's growing influence in the global Information Communication and Technology sector, its large potential for economies of scale in many aspects, and the government's capacity to control national access to, and flows of, electronic data and information, have also been seen as part of the growing capacity to challenge U.S. dominance, triggering the kinds or responses witnessed in the lead up to the so-called truce (Ciuriak, 2019), including sanctions against Chinese data companies, such as Huawei.

Third, and equally important, is the global logistics and trade flows aspect. It is a historically sustained fact that control over key global transport nodes and corridors guarantees national economic prosperity (Chhetri et al., 2018). As observed by Baldwin (2016), enhancing IT technology and declining logistics costs have driven the 'great global convergence' over the past three decades. The global economy has become increasingly and intricately integrated, and the global value chain has been progressively streamlined with China emerging as the global production powerhouse and the most successful economy in the global production and distribution system (McKay and Song, 2010). China's growing command in the design, production and application of advanced technologies of production such as AI and robotics and its growing investment in, and control of, transport and logistics infrastructure in Asia and large parts of the developing world, e.g. through the Belt and Road Initiative (BRI), ensures its position as the major force in the fourth industrial revolution. In this, as well, its course is charted in a direct collision with America's global economic control.

It is in this third respect that this Special Issue of Journal of International Logistics and Trade (JILT) is developed with specific 
focus on the BRI. Since its inception in 2013, the BRI has progressively developed to represent a microcosm of the antagonism between the U.S. and China. Academic and policy commentators have taken sides with some hailing the great global transport connectivity advantages it brings while others have conjured sinister motives such as Chinese expansionism (Cheng, 2016; Djankov and Miner, 2016; Liu and Dunford, 2016; Wang, 2016). The Issue includes selected topics that have significant impact on the outcomes of BRI. Rather than focus strictly on BRI issues, this collection examines a broader range of topics, including technological transformations, supply chain integration and the implications of population ageing on the real exchange rates.

The first paper, "The consequences of information technology, information sharing, and supply integration, towards supply chain performance and firm performance,” by Veera Pandiyan Kaliani Sundram, Ali Hussein Zolait, Atikah Shamsul Bahrin, examined the role of information technology and information sharing in a manufacturing supply chain, and its contribution towards supply chain integration, supply chain performance, and manufacturing firm performance in Malaysia. Based on a survey questionnaire administered to 112 manufacturing firms in Malaysia, the paper shows that information technology and sharing have significant positive effects on performance. The authors argue that firms should adopt appropriate information technology and information sharing practices to improve their strategic supply chain integration. This, in turn, will also improve the supply chain network and the firm's performance.

The second paper, "Population age structure and real exchange rate in OECD countries: an empirical analysis,” written by Kamrul Hassan, Ruhul Salim, and Harry Bloch, examined the impacts of population age structure on the real exchange rate. Based on the panel data of 22 OECD countries, the paper reported that young dependents, through their demand for non-traded goods, exert a depreciating effect on the real exchange rate, while the increased share of older people in the population place negative pressure on domestic saving, leading to capital inflow and real appreciation. A share of the working-age population was found to have an appreciating effect on the real exchange rate. The authors argue that to deal with the effects of population aging, governments may adopt a policy to save more for the future, such as by reducing/increasing budget deficit/surplus, reducing the tax-free threshold income level, or increasing the effective retirement age.

The third Paper, “Container Terminal ICT Systems Implementation; Challenges and Outcomes,” written by Victor Gekara and Xuan-Vi Thanh Nguyen, examined the factors that influenced the outcomes of the implementation of computer-based container terminal operating systems at the Port of Mombasa. The study utilized a qualitative single-case method involving a combination of semi-structured interviews, non-participant observations and content analysis of relevant policy reports. The authors find that the attempt to adopt and implement TOS at the port mostly failed as a result of a complex combination of technological, organisational and environmental factors. Most importantly, there was a general lack of appropriately skilled workers to support the technology as well as a wider business environment ill equipped with the necessary ICT infrastructure to support effective implementation.

\section{References}

Allison, G., 2017. Destined for War, Can America and China Escape Thucydidies’s Trap? Houghton Mifflin, New York, NY.

Baldwin, R., 2016. The Great Convergence: Information, Technology and the New Globalization. Belknap Press of the Harvard University Press, Cambridge, MA.

Cheng, L. K., 2016. Three questions on China's “Belt and Road Initiative”, China Economic Review 40, 309-313.

Chhetri, P., Nkhoma, M., Peszynski, K., Chhetri, A., Lee, P. T. W., 2018. Global logistics city concept: A cluster-led strategy under the belt and road initiative. Maritime Policy and Management 45, 319-335.

Ciuriak, D., 2019. The US-China trade war: Technological roots and WTO responses. Global Solutions Journal 4, 130-135.

Djankov, S., Miner, S., 2016. China's Belt and Road Initiative: Motives, Scope, and Challenges. Peterson Institute for International Economics, Washington, DC.

Liu, W., Dundford, M., 2016. Inclusive globalization: Unpacking China's belt and road initiative. Area Development and Policy 1, 323-340.

McKay, H., Song, L., 2010. China as a Global Manufacturing Powerhouse: Strategic Considerations and Structural Adjustment. China \& World Economy, 18, 1-32.

Wang, Y., 2016. Offensive for defensive: The belt and road initiative and China's new grand strategy. The Pacific Review 29, 455-463. 